\title{
RISK OF INTEREST RATES AT THE LEVEL OF COMMERCIAL BANKS IN ROMANIA
}

\author{
Ioana Raluca SBÂRCEA \\ "Lucian Blaga" University of Sibiu, Romania \\ ioana.sbarcea@ulbsibiu.ro
}

\begin{abstract}
The banking system in Romania is a banking system under development, subject to fluctuations that exist on the market more than on more developed banking systems, fluctuations that can generate losses for banks if they are not properly managed. The losses that may be generated by these fluctuations, known as market risk, refer to the significant fluctuations in three indicators, namely the interest rate, the exchange rate and the asset price. In this article, I will analyse the interest rate risk from a conceptual point of view and the indicators that mitigate this risk. The analysis also contains a study of this risk among commercial banks in the system to highlight the level of risk and possible effects of its manifestation. I calculated and analysed the interest rate risk indicators, individually for the first three banks in the system, but also to comparatively, in order to highlight the existing differences.
\end{abstract}

KEYWORDS: interest rate, market risk, sensitivity index, GAP, banking system

\section{Introduction}

The banking market is the market that wants to be the most stable, considering that the existing liquidity is being mobilized and managed in an economy, so its malfunctioning can lead to malfunctions in all sectors. However, the banking system is affected by market indicators, mainly due to fluctuations in the interest rate, the exchange rate and the value of assets. These changes affect the value of bank assets, which can generate bank losses. In this paper I proposed to analyse one of the market risks, namely the interest rate risk, which should be predicted by the bank and prevented by specific measures. Interest rate changes can reverse the relationship between interest rates on assets and liabilities, and the analysis of losses that may arise as a result of credit risk exposure involves a maturity bandwidth analysis of assets to highlight periods where the bank has to protect itself against unfavourable fluctuations. The analysis I intend to do will start with a conceptual analysis of the interest rate risk and its rating indicators, followed by an analysis of the situation of the first three commercial banks on these indicators, in order to reflect the assumed risk in each case, and comparatively with the other banks.

\section{Literature Review}

Market risk, and in this case the interest rate risk, is frequently debated by researchers in the field. Thus, Saunders and Cornett consider that the interest rate risk is determined by the inconsistency or lack of 
correlation between the maturity of the elements of assets and liabilities (Saunders \& Cornett, 2008). Analysing the bank's financial statements, we can see that deposits are generally demanded in the short term and in a very small proportion in the medium term, and the loans are required in the long term. The discrepancy between the maturity bands of assets and liabilities is the main cause that may generate interest rate risk.

Badea, L., (2010) considers that the difference that exists between the value of a portfolio of financial assets and the value of liabilities that finance that portfolio or the effect of changing interest rates on the value of a financial asset defines interest rate risk. According to the Brock and Franken interest rate analysis in 2003, it was concluded that this could be due to the bank's balance sheet, monetary policy and bank concentration (Brock \& Franken, 2003).

Gomez, M., Landier A., Sraer D, $\&$ Thesmer, D. (2016) studied the effect of banks' exposure to interest rate risk on the way monetary policy is transmitted to the real economy. Their analysis of the US banking system highlighted that when the Federal Reserve increases short-term interest rates banks' flows are affected, which has an impact on lending activity.

The manifestation of the interest rate risk is favoured by three aspects, according to Armeneanu, Bălu and Obreja: the lack of accordance between the maturities of the assets and the liabilities elements, the difference between the active and the passive interest and the double correlation between the risk manifestation and the performance of the banking activity. (Armeneanu, Bălu \& Obreja, 2008).

Thus, interest rate risk is a risk with repercussions both at the level of commercial banks and their patrimonial value, but also at the level of the economy if we consider the link between this risk and the monetary policy.
The interest rate risk must be monitored permanently so that it can intervene early if a possible occurrence of the risk materializes. For this monitoring, Badea (2010) proposes a set of indicators starting from the grouping of asset and liability items on maturity bands and highlighting their sensitivity to changes in the interest rate, i.e. the impact of this change on the bank's interest margin. Of these indicators, I consider relevant two indicators that can highlight the level of exposure to interest rate risk, respectively:

-The GAP is the difference between the value of assets and liabilities sensitive to the interest rate, at a given point in time. The main assets sensitive to the interest rate are the loans granted and the financial securities in which the bank invested and the main sensitive liabilities refer to the loans borrowed from the other banks and the central bank and, of course, the deposits attracted from the clients. The interpretation of this indicator is interesting and should be correlated with the performance level targeted by the bank. Thus, the optimal situation would be that the GAP is as close as possible to zero. If this does not happen, and interest-sensitive assets are larger than sensitive liabilities, then rising interest rates will result in higher net interest income (net interest income are also called net interest and is calculated as the difference between the active and passive interest rates of the bank). If the situation is reverse, i.e. sensitive assets are below the level of sensitive liabilities, then we will say that the GAP is negative, and the bank will see a decrease in net interest rates, with an increase in interest rates.

- Sensitivity index, calculated as the ratio between sensitive assets and sensitive liabilities at a given time. Interest rate risk is lower if the level of the indicator is around 1 , but this level is not necessarily desired by banks because it would imply a loss of profitability (Badea, 2010). 
In this context, in terms of the indicators by which banks can monitor the interest rate risk, another aspect they can achieve is to find ways to protect themselves against it, which is mainly about the permanent analysis of differences between assets and liabilities, off-thebalance sheet transactions (futures, options contracts) to cancel out unfavourable positions, and scenarios to reflect the time needed for a bank to take action to recover funds mobilized for financial investment.

Moreover, the bank should analyse this market risk in direct correlation with the liquidity risk, since a favourable market risk situation seen in terms of net interest growth if the interest rate increases and the bank has an overall positive GAP can be regarded as an unfavourable situation in terms of liquidity risk, because this positive GAP is in fact a preponderant financing of long-term assets from short-term liabilities, which may put pressure on the bank's liquidity at certain times. Another correlation to be made is between interest rate risk and credit risk, as an increase in interest may mean an increase in interest earned on asset items, as well as additional pressure on borrowers that may not be able to return their loans.
In this context, market risk needs to be carefully analysed, as it can generate other risks but can also generate higher performance.

3. Study on Interest Rate Risk Rating Indicators in the Commercial Banks from the Romanian Banking System

In this paper, I proposed to conduct a case study on the exposure of the first three banks in the Romanian banking system (BCR, Transilvania Bank, and BRD) to the interest rate risk. The analysis will be carried out for the period 2010-2016 at the level of each bank, as well as comparatively to highlight the differences between them. It should be noted that Transilvania Bank in 2010 was not among the top 3 Romanian banks, only in 2011 it entered and occupied the third position until 2015, when it became the second bank in Romania. We will highlight its situation and we will see to what extent the management of the patrimonial elements has had to do with the ascension of Transilvania Bank, or how this rise has affected its exposure on the market risk.

Regarding the interest rate risk rating indicators at $\mathrm{BCR}$, these are presented in detail in Table no 1.

Table no. 1

The situation of the GAP and the sensitivity index for $B C R$ between 2010-2016 (thousands of lei)

\begin{tabular}{|c|c|c|c|c|c|}
\hline \multirow{2}{*}{ Year } & Maturity band & Sensitive assets & $\begin{array}{c}\text { Sensitive } \\
\text { liabilities }\end{array}$ & GAP & Sensitivity index \\
\hline \multirow{2}{*}{2010} & $<12$ months & 32.426 .932 & 37.194 .259 & $-4,767,327$ & 0.87 \\
\cline { 2 - 6 } & $>12$ months & 37.518 .255 & 25.631 .290 & $11,886,965$ & 1.46 \\
\hline \multirow{2}{*}{2011} & $<12$ months & 28.012 .731 & 39.948 .396 & $-11,935,665$ & 0.70 \\
\cline { 2 - 6 } & $>12$ months & 45.871 .100 & 26.087 .938 & $19,783,162$ & 1.76 \\
\hline \multirow{2}{*}{2012} & $<12$ months & 27.954 .590 & 42.700 .915 & $-14,746,325$ & 0.65 \\
\cline { 2 - 6 } & $>12$ months & 44.576 .593 & 20.706 .963 & $23,869,630$ & 2.15 \\
\hline \multirow{2}{*}{2013} & $<12$ months & 44.229 .841 & 50.554 .040 & $-6,324,199$ & 0.87 \\
\cline { 2 - 6 } & $>12$ months & 15.561 .591 & 3.419 .911 & $12,141,680$ & 4.55 \\
\hline \multirow{2}{*}{2014} & $<12$ months & 22.189 .224 & 40.361 .254 & $-18,172,030$ & 0.55 \\
\cline { 2 - 6 } & $>12$ months & 36.847 .910 & 13.564 .983 & $23,282,927$ & 2.72 \\
\hline \multirow{2}{*}{2015} & $<12$ months & 24.378 .765 & 40.366 .354 & $-15,987,589$ & 0.60 \\
\cline { 2 - 6 } & $>12$ months & 35.082 .148 & 13.195 .333 & $21,886,815$ & 2.66 \\
\hline \multirow{2}{*}{2016} & $<12$ months & 22.000 .799 & 42.067 .426 & $-20,066,627$ & 0.52 \\
\cline { 2 - 6 } & $>12$ months & 45.640 .533 & 11.535 .459 & $34,105,074$ & 3.96 \\
\hline
\end{tabular}

(Source: Processing after the consolidated financial statements of BCR for the period 2010-2016, www.bcr.ro) 
Analysing the situation of assets and liabilities sensitive to the change in the interest rate, we note that for BCR, the GAP complied with a rule, namely it was negative throughout the analysed period for the patrimonial items with a maturity of less than 12 months and was positive throughout the analysed period for assets and liabilities with a maturity of more than 12 months. This aspect reflects, on the one hand, a way of functioning of this bank, namely the fact that it manages to attract more resources with short term maturity than manages to place short term assets, and, from the perspective of the long-term situation, it is exactly the opposite, and it places more in the long term than attracts in the long term. Looking at the GAP in absolute figures, we can see that the value with which long-term assets exceed longterm liabilities is significantly higher than absolute GAP in the short term. Analysing this situation from the point of view of the interest rate fluctuation risk, I may say that $\mathrm{BCR}$, if the market interest rate increases, in the short term it would register a decrease in the net interest rate, and in the long term it would gain from this difference between the active and the passive interest rates, and overall the bank would benefit from the increase in interest. This is also confirmed by the sensitivity index, which is higher in the long term than in the shortterm. But if this rising market interest rate persists, the bank may experience pressure from long-term liquidity risk, with the resources attracted by these terms not covering long-term investments.

Regarding the market risk situation at BRD-GSG, the indicators for the measurement of this risk are presented in detail in Table no. 2 for the period 2010-2016.

Situation of the GAP and the sensitivity index for BRD-GSG

Table no. 2

between 2010-2016 (thousands of lei)

\begin{tabular}{|c|c|c|c|c|c|}
\hline \multirow{2}{*}{ Year } & Maturity band & Sensitive assets & $\begin{array}{c}\text { Sensitive } \\
\text { liabilities }\end{array}$ & GAP & Sensitivity index \\
\hline \multirow{2}{*}{2010} & $<12$ months & 41.368 .203 & 41.573 .670 & $-205,467$ & 0.995 \\
\cline { 2 - 6 } & $>12$ months & 6.920 .105 & 1.137 .440 & $5,782,665$ & 6.084 \\
\hline \multirow{2}{*}{2011} & $<12$ months & 39.543 .831 & 41.258 .620 & $-1,714,789$ & 0.958 \\
\cline { 2 - 6 } & $>12$ months & 9.207 .167 & 1.602 .141 & $7,605,026$ & 5.747 \\
\hline \multirow{2}{*}{2012} & $<12$ months & 37.845 .650 & 41.503 .832 & $-3,658,182$ & 0.912 \\
\cline { 2 - 6 } & $>12$ months & 10.078 .409 & 913.145 & $9,165,264$ & 11.037 \\
\hline \multirow{2}{*}{2013} & $<12$ months & 38.325 .350 & 40.605 .719 & $-2,280,369$ & 0.944 \\
\cline { 2 - 6 } & $>12$ months & 8.753 .753 & 1.312 .405 & $7,441,348$ & 6.670 \\
\hline \multirow{2}{*}{2015} & $>12$ months & 30.758 .863 & 29.386 .510 & $1,372,353$ & 1.047 \\
\cline { 2 - 6 } & $>12$ months & 13.419 .948 & 9.811 .800 & $3,608,148$ & 1.368 \\
\cline { 2 - 6 } & $>12$ months & 33.211 .311 & 23.148 .901 & $10,062,410$ & 1.435 \\
\hline \multirow{2}{*}{2016} & $<12$ months & 14.312 .696 & 10.463 .082 & $3,849,614$ & 1.368 \\
\cline { 2 - 6 } & $>12$ months & 16.387 .460 & 10.595 .037 & $-578,123$ & 0.982 \\
\hline
\end{tabular}

(Source: Processing after the consolidated financial statements of BRD for the period 2010-2016, www.brd.ro)

Analysing the situation of market risk measurement indicators at BRD-GSR, we can no longer observe a rule of GAP's signs throughout the analysed period, i.e. we notice that in the half of the analysed period (2010-2013) the GAP is negative term for up to one year and positive for a period longer than one year, for the second half of the analysed period it becomes negative at both intervals, with an exception in 2016 when it is negative for assets and liabilities of less than 12 months. BCR's situation is very interesting in the years 2014 and 2015, as the recording of a positive short-term 
GAP and an over-unit sensitivity index reflect a slight reorientation of the bank towards short-term placement of the attracted resources, which can generate net interest income if interest in the market increases. However, the bank must exercise caution in managing these assets in the short term, because if there are problems with repayment, they may have problems from the liquidity risk perspective. What is also worth noting is the significant decrease in the long-term sensitivity index from 11,037 in 2012 to 1,547 in 2016, which may reflect lower net interest rates in the case of the rise in the benchmark interest rate, but which may reflect much more good liquidity and a lower market and liquidity risk. $\mathrm{BRD}$, together with $\mathrm{BCR}$, was also one of the banks that had to take off-balance sheet assets by selling them to specialized companies in forced recovery, due to losses due to the inability to pay of the customers affected after the start of the financial crisis in 2008.

Regarding the situation of the market risk assessment indicators at Transilvania Bank, they are presented in detail in the Table no. 3 .

The situation of the GAP and the sensitivity index for Transilvania Bank Between 2010-2016 (thousands of lei)

\begin{tabular}{|c|c|c|c|c|c|}
\hline Year & Maturity band & Sensitive assets & Sensitive liabilities & GAP & Sensitivity index \\
\hline \multirow{2}{*}{2010} & $<12$ months & 20.165 .899 & 19.295 .672 & 870,227 & 1.045 \\
\cline { 2 - 6 } & $>12$ months & 906.423 & 167.502 & 738,921 & 5.411 \\
\hline \multirow{2}{*}{2011} & $<12$ months & 24.380 .074 & 23.133 .577 & $1,246,497$ & 1.054 \\
\cline { 2 - 6 } & $>12$ months & 1.092 .350 & 227.985 & 864,365 & 4.791 \\
\hline \multirow{2}{*}{2012} & $<12$ months & 27.296 .167 & 25.866 .505 & $1,429,662$ & 1.055 \\
\cline { 2 - 6 } & $>12$ months & 1.797 .948 & 671.330 & $1,126,618$ & 2.678 \\
\hline \multirow{2}{*}{2014} & $<12$ months & 29.208 .720 & 28.596 .204 & 612,516 & 1.021 \\
\cline { 2 - 6 } & $>12$ months & 2.446 .971 & 48.430 & $2,398,541$ & 50.526 \\
\cline { 2 - 6 } 2015 & $>12$ months & 32.314 .732 & 31.444 .836 & 869,896 & 1.028 \\
\cline { 2 - 6 } & $<12$ months & 2.885 .236 & 130.858 & $2,754,378$ & 22.049 \\
\hline \multirow{2}{*}{2016} & $>12$ months & 2.587 .848 & 39.539 .624 & $-7,951,776$ & 0.799 \\
\cline { 2 - 6 } & $>12$ months & 31.844 .101 & 973.700 & $1,721,184$ & 2.768 \\
\hline
\end{tabular}

(Source: Processing after the consolidated financial statements of Transilvania Bank for the period 2010-2016, www.bancatransilvania.ro)

Analysing the situation of the GAP and the sensitivity index at Transilvania Bank, we may notice that its situation is somewhat mirroring that of BRD. Thus, if Transilvania Bank registered a positive GAP both in the short and long term by 2014, in 2015 and 2016, the GAP became negative in the short term and positive in the long term. We can observe that in the period 2010-2012, the short-term sensitivity index was very close to the theoretically considered optimal level, reflecting a proper management of short-term assets and liabilities with low market risk. We also notice an increase in long-term investments of Transilvania Bank since 2011, a gradual increase but which could not be supported by an increase in the comparable amplitude of long-term attracted resources (confirmed by the record of a long-term sensitivity index in 2013 of 50,526, far too high compared to the optimum level). Transilvania Bank managed this situation, and in the following periods we also observed a gradual increase in liabilities, so that in the year 2016, the long-term sensitivity index reached 2,709. Looking at the situation at Transilvania Bank as a whole, we see a strategic change in the approach of assets and liabilities, 
respectively the slight decrease of the assets placed in the short term and the gradual increase of the long-term assets, in the conditions of an increase of the liabilities attracted in the short term, and in a sustained way of those attracted in the long term. This change may have two possible causes, on the one hand, the increase in the long-term financing demand in recent years, and on the other hand the transition of Transilvania Bank to the second position in the Romanian banking ranking, which makes it more attractive for deposit placements for longer terms, but also for long-term loan demands. From a market risk perspective, an increase in the interest rate may generate long-term interest rate increases, and their decline in the short term. However, if from the liquidity risk perspective, Transilvania Bank is well on the short term, an advanced short-term asset growth, which is not also sustained by a similar increase of long-term liabilities, may generate liquidity problems.

The comparative analysis of the GAP situation at the level of the first banks in Romania is presented according to Charts no. 1 and 2, and reflects the differences between the three banks and different strategic approaches.

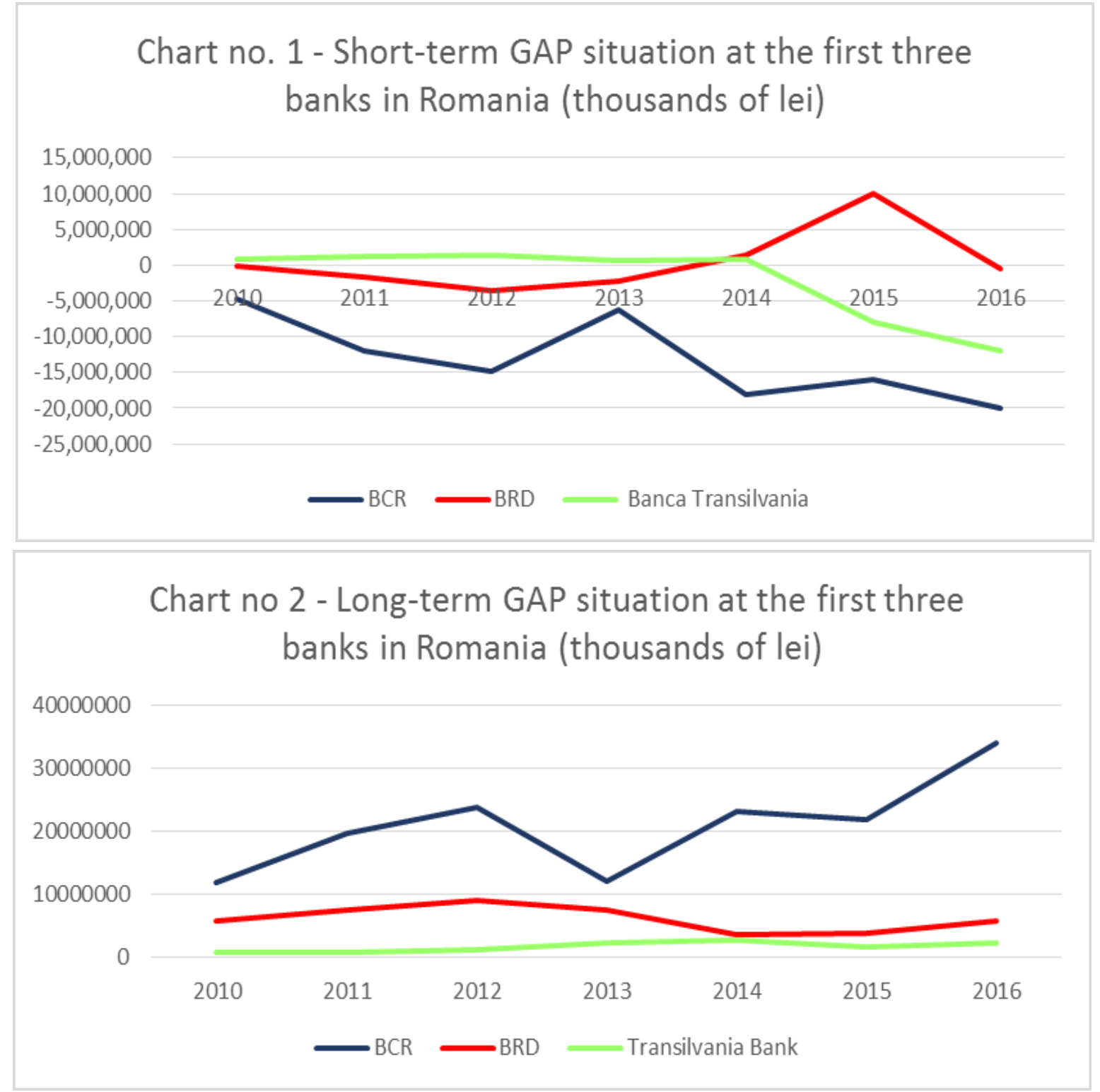

(Source: Processed data from Table no. 1, 2 and 3) 
By analysing comparatively the shortterm GAP at the level of the three banks, we observe size differences and, although the general trend present at the level of the three banks in 2016 is the decrease of this indicator, the evolutions were different over the period under review. Thus, we notice the maintenance of BCR's negative GAP throughout the analysed period, being a renowned bank in Romania, which enjoys the trust of its clients to keep their savings here, even if they do so in the short term. The exact same situation of GAP at BRD versus Transilvania Bank since 2014 highlights different strategic visions and different contexts, respectively, BRD is a bank which really felt the effects after the 2008 crisis, which has incurred losses due to bad loans and which was forced to sell some of them to clean up its portfolio and Transilvania Bank is a bank less affected by the crisis, which had a sustained growth after the crisis and managed to deal with its credit risk better than the other banks, aspects that reflect a certain caution, but also growth that has allowed it to rise to the second position in the ranking of Romanian banks. We see Transilvania Bank interested in providing long-term financing, which may generate higher interest rates, but also an extra exposure to liquidity risk.

With regard to the long-term GAP, we note that all banks have a positive GAP, justified by the need for long-term client financing, somewhat in opposition to the customer's confidence to place cash at the bank in the short-term. However, the difference in size between GAPs of the analysed banks is again to be noticed. Therefore, Transilvania Bank maintains a lower GAP than the other banks, BRD approaches the absolute level of Transilvania Bank's GAP, but there were moments in the analysed period when BRD was more similar to BCR in terms of this indicator. The main reason for this is that there is a caution in the long-term exposure at BRD in order to avoid the post-2008 situation. BCR's long-term gap has currently made a considerable advance, the main reason being the demand from customers, a time when the construction and housing sector is growing again. Although in terms of profitability, the situation may be favourable for BCR in terms of the rise in the benchmark interest rate, at the same time it can generate credit and liquidity risk, especially if the situation persists.

\section{Conclusions}

Analysing the market risk, we note that its measurement is not a cumbersome one, but instead it can be difficult to interpret the results of market risk measurement indicators, i.e. it is difficult to say whether or not the bank is exposed to this risk. This is because the market risk cannot be analysed individually, but only in correlation with the liquidity risk, credit risk and profitability of the bank. Thus, assuming that in an economy the benchmark interest rate increases and a bank records a positive GAP in the long term, namely the assets sensitive to the change in interest are higher than the sensitive liabilities, in terms of bank profitability, the situation generates a clear advantage from the perspective of positive net interests. However, the same situation, coupled with the inability of customers who have long-term credits to assimilate the increase in interest rates and continue to be good-payers, turns into a totally unfavourable situation for the bank, because in the long term those loans can become non-performing (credit risk manifestation), and at the same time the liquidity risk can be manifested, and the bank will have to find other sources to repay long-term debt or to incur certain losses. This conclusion also applies to the three analysed banks which, from my perspective, should constantly monitor interest rate risk in relation to credit risk, liquidity risk and with the expected financial performance. 


\section{REFERENCES}

Armeneanu, D., Bălu, F. O., \& Obreja, C. (2008). Managementul riscului de rată a dobânzii prin utilizarea metodei GAP-ului de durată, Revista Economică Teoretică și Aplicată, $n r .1$.

Badea, L. (coord.), Socol A., Drăgoi V., \& Drigă, I. (2010). Managementul riscului bancar, Bucureşti: Editura Economică, 78-79.

Brock, P., \& Franken, H. (2003). Measuring the Determinants of Average and Marginal Bank Interest Rate Spreads in Chile 1994-2001, Working Papers, University of Washington, Department of Economics, 25.

Financial statements of BCR from 2010-2016, available at: www.bcr.ro.

Financial statements of BRD from 2010-2016, available at: www.brd.ro.

Financial statements of Transilvania Bank from 2010-2016, available at: www.bancatransilvania.ro.

Gomez, M., Landier, A., Sraer, D., \& Thesmer, D. (2016). Banks exposure to interest rate risk and the transmission of monetary policy, Working Papers Series, 13.

Saunders, A., \& Cornett, M. M. (2008). Financial Institutions Management - A Risk Management Approach, New York: McGraw Hill Irwin Publishing, 169. 